\title{
Article \\ Effect of Saline-Nutrient Solution on Yield, Quality, and Shelf-Life of Sea Fennel (Crithmum maritimum L.) Plants
}

\author{
Fabio Amoruso ${ }^{1,2}$, Angelo Signore ${ }^{2}$, , Perla A. Gómez ${ }^{3}$, María del Carmen Martínez-Ballesta ${ }^{1,3}$ (D), \\ Almudena Giménez ${ }^{1}{ }^{(\mathbb{D}}$, José A. Franco ${ }^{1,3}{ }^{\mathbb{D}}$, Juan A. Fernández ${ }^{1,3} \mathbb{D}$ and Catalina Egea-Gilabert $1,3, * \mathbb{D}$ \\ 1 Department of Agronomical Engineering, Universidad Politécnica de Cartagena, \\ 30203 Cartagena, Murcia, Spain; f.amoruso17@uniba.it (F.A.); mcarmen.ballesta@upct.es (M.d.C.M.-B.); \\ almudena.gimenez@upct.es (A.G.); josea.franco@upct.es (J.A.F.); juan.fernandez@upct.es (J.A.F.) \\ 2 Department of Agricultural and Environmental Science, University of Bari Aldo Moro, 70126 Bari, Italy; \\ angelo.signore@uniba.it \\ 3 Institute of Plant Biotechnology, Universidad Politécnica de Cartagena, 30202 Cartagena, Murcia, Spain; \\ perla.gomez@upct.es \\ * Correspondence: catalina.egea@upct.es
}

check for updates

Citation: Amoruso, F.; Signore, A.; Gómez, P.A.; Martínez-Ballesta, M.d.C.; Giménez, A.; Franco, J.A.; Fernández, J.A.; Egea-Gilabert, C. Effect of Saline-Nutrient Solution on Yield, Quality, and Shelf-Life of Sea Fennel (Crithmum maritimum L.) Plants. Horticulturae 2022, 8, 127. https://doi.org/10.3390/

horticulturae 8020127

Academic Editors: Rosario

Paolo Mauro, Carlo Nicoletto and Leo Sabatino

Received: 30 December 2021

Accepted: 27 January 2022

Published: 30 January 2022

Publisher's Note: MDPI stays neutral with regard to jurisdictional claims in published maps and institutional affiliations.

Copyright: (C) 2022 by the authors. Licensee MDPI, Basel, Switzerland. This article is an open access article distributed under the terms and conditions of the Creative Commons Attribution (CC BY) license (https:// creativecommons.org/licenses/by/ $4.0 /)$.

\begin{abstract}
In this study, the effect of salinity $(150 \mathrm{mM} \mathrm{NaCl})$ compared to a control $(9 \mathrm{mM} \mathrm{NaCl})$ on growth, quality and shelf-life of fresh-cut sea fennel was evaluated. For that, sea fennel plants were cultivated in a hydroponic floating system and the sea fennel leaves were stored for 12 days at $5{ }^{\circ} \mathrm{C}$. At harvest, leaves from plants grown in salinity had a lower content of $\mathrm{NO}_{3}{ }^{-}, \mathrm{K}^{+}$and $\mathrm{Ca}^{2+}$ and an increased $\mathrm{Cl}^{-}$and $\mathrm{Na}^{+}$concentration when compared to the control. There was a positive effect in the aerial part with increased fresh weight due to salt stress, but a reduction in the root biomass. During storage, weight loss and colour changes were not significant while leaves' firmness was higher for control and increased during storage, probably due to lignification. Microbial growth (psychrophiles, yeast and moulds and enterobacteria) was higher at harvest for control and increased during storage, with no differences between treatments after 12 days at $5{ }^{\circ} \mathrm{C}$. Sensory quality was similar for both treatments but leaves from $\mathrm{NaCl}$ treatment had a salty taste that was easily detected by panelists. These results show that saline-nutrient solution applied in hydroponics is a suitable system for sea fennel growth. It gives a slightly salty but high-quality product, acceptable as a "ready-to-eat" vegetable.
\end{abstract}

Keywords: salinity; microbial growth; sensory quality; floating system; ready-to-eat

\section{Introduction}

Sea fennel (Crithmum maritimum L.), also known as crest marine, marine fennel, samphire, and rock samphire [1], is a halophyte species, the sole one of the Crithmum genus [2,3], which belongs to the Apiaceae family.

This species is widespread in the Mediterranean coasts as well in the Canary Islands [2] and along the Atlantic coast of Portugal, England, Wales and Southern Ireland [4].

Being a perennial halophyte species, it is able to grow in sand hills or on rocky cliffs and is remarkably productive under saline conditions to exploit seawater, coastal lands, and other marginal areas otherwise useless [5], without requiring huge allocation and depletion of freshwater resources [6].

Its distinguishing sensory attributes in terms of taste, odour and colour has historically always found applications in culinary Mediterranean tradition and the food industry [1,7], and in some countries (e.g., Italy) its use is so long and rooted in time that such a product is included in the "List of Traditional Agri-Food Products" of the Italian Department for Agriculture [1]. Sea fennel importance is not limited only to the culinary uses (mainly as an appetizer), but also as carminative, diuretic or for treating obesity [8]. In addition, it is rich in several biologically active compounds (ascorbic acid, iodine, carotenoids, 
flavonoids, organic acids, phenolics, etc.) [9], exerting beneficial effects against oxidative or mutagenic mechanisms, and pathogenic bacteria [10], which is important for their healthy properties [11,12].

Apart from its use as a fresh product, Renna et al. [1] proposed sea fennel to be used in dried form with different techniques of drying, as this could lead to an "industrial production on a large scale and also to diversify local food through a micro-scale production".

Similar to other halophyte species, sea fennel has developed mechanisms to tolerate high salinity levels, particularly by accumulating $\mathrm{Na}^{+}$and $\mathrm{Cl}^{-}$into the vacuoles [13]. Furthermore, Jiménez-Becker et al. [14] observed that sea fennel has the capacity, compared to other halophytes, to reduce the uptake of $\mathrm{Cl}^{-}$, which results in a lower concentration within the leaves and to an increase in the concentration of soluble sugars and proline, in particular at high salinity levels (300 $\mathrm{mM}$ of $\mathrm{NaCl})$.

Yet, even if products of halophytes species are produced more and more and sold in the markets worldwide, sea fennel may be still considered as a wild edible plant, since it has not undergone a structured programme for its genetic improvement and cultivation, even if it could be easily domesticated and engineered to exploit its beneficial elements content $[15,16]$. Recent knowledge suggests that sea fennel shows good potential as an emerging crop, despite studies on its cultivation techniques being limited [17]. A floating system seems to be particularly appropriate for baby leaf vegetable production since it allows precise control of plant nutrition and the maximisation of yield and quality of the product. Thus, Giménez et al. [18] demonstrated that the above system is a suitable method for growing C. maritimum. It is well known that cultivation conditions influence the quality of the raw material and therefore can modify its physiological behaviour and suitability for fresh-cut processing [19]. We hypothesise that any preharvest condition that stresses a plant, such as the salinisation of the nutrient solution, could affect the quality and shelf-life of the sea fennel, particularly increasing the phytochemicals of the plant.

In our vision, sea fennel has the potential for more extensive cultivation and for the ready-to-eat market as a baby-leaf vegetable, due not only to its organoleptic characteristics but also to its richness in terms of health-promoting compounds and its suitability for cultivation in saline conditions, an important aspect for the Mediterranean environment. This aspect would be crucial since soil salinity is currently the most important environmental stress limiting crop production in arid and semi-arid areas [20], and, in the near future this trend is expected to worsen [21]. For this purpose, we evaluated the effect of the salinity level of the nutrient solution in a floating system on the growth, quality, and shelf-life of C. maritimum during a storage period.

\section{Materials and Methods}

\subsection{Plant Material and Growing Conditions}

The experiment was conducted in an unheated greenhouse covered with thermal polyethylene located at the Experimental Agro-Food Station, Technical University of Cartagena (UPCT; lat. 3741' N; long. 057' W), using seeds provided by Semillas Cantueso, obtained in Dunas de Artola, (Málaga). Sowing was carried out manually into "styrofloat" trays of $60 \mathrm{~cm} \times 41 \mathrm{~cm}$ containing peat. The trays were placed in a growth chamber at $20{ }^{\circ} \mathrm{C}$ for 5 days and then transferred to flotation beds, floating on fresh tap water with an electrical conductivity (EC) of $1.1 \mathrm{dS} \mathrm{m}^{-1}$ and a $\mathrm{pH}$ of 7.8. Aeration was provided using a blow pump connected to a pipe trellis positioned at the bottom of each flotation bed. Each level of treatment was carried out in $135 \mathrm{~cm} \times 125 \mathrm{~cm} \times 20 \mathrm{~cm}$ beds located at three places inside a greenhouse for all the experiments. A week after transferring to the floating beds, the plants were thinned, leaving a plant density around 400 plants $\mathrm{m}^{-2}$, and the nutrient solution was added to the water and adjusted to EC $2.7 \mathrm{dS} \mathrm{m}^{-1}$ and the $\mathrm{pH}$ to 5.8 [22]. After 30 days, $\mathrm{NaCl}$ was added to the nutrient solution to half of the plants to reach a concentration of $150 \mathrm{mM}$, while the other half was set as control treatment $(9 \mathrm{mM}$ of $\mathrm{NaCl})$. The EC and temperature of the nutrient solution were monitored during the growing cycle 
using sensors (CS547 Campbell Scientific Inc., Logan, UT, USA). Harvesting was carried out when plants had four-five pairs of leaves.

\subsection{Analysis at Harvesting Time}

Shoot fresh weight (FW), leaf area, specific leaf area (SLA) and root growth parameters were measured on 10 plants in each tray. Leaf area was measured using a leaf area meter (LICOR-3100 C; LICOR Biosciences Inc., Lincoln, NE, USA). Root length, area, and volume, and the number of branches were determined using a Winrhizo LA 1600 root counter (RegentInc., Quebec, QC, Canada) from pictures taken of each root system by a double-pass scanner incorporated in the counter. The dry weight (DW) of the shoot was determined by drying in an oven at $60^{\circ} \mathrm{C}$ until constant weight.

At harvesting, the following biochemical parameters were measured in the sea fennel leaves: ions content, total phenolics and flavonoids content and total antioxidant capacity. The ions content was determined and quantified following the method described by Lara et al. [23] in the sea fennel leaves. Ions were extracted in triplicate per treatment. The extraction of $0.2 \mathrm{~g}$ of dry leaf samples of each treatment was carried out with $50 \mathrm{~mL}$ distilled water and continuous agitation in an orbital shaker (Stuart SSL1, Stone, UK) for $45 \mathrm{~min}$ at $110 \mathrm{rpm}$ at $50^{\circ} \mathrm{C}$. Ion concentrations were determined by ion chromatography using a Metrosep A SUPP 5 column (Metrohm AG, Zofingen, Switzerland) at a flow rate of $0.7 \mathrm{~mL} \mathrm{~min}^{-1}$ for anions and a Metrosep C 2-250 column at a flow rate of $1.0 \mathrm{~mL} \mathrm{~min}^{-1}$ for cations, following the manufacturer's instructions.

The total phenolic content was determined using the Folin-Ciocalteu colorimetric method, modified by Everette et al. [24]. A $50 \mu \mathrm{L}$ aliquot of the methanolic extract supernatant was mixed with $50 \mu \mathrm{L}$ of Folin-Ciocalteu reagent and $750 \mu \mathrm{L}$ of $\mathrm{H}_{2} \mathrm{O}$. The solution was incubated for $5 \mathrm{~min}$ and $150 \mu \mathrm{L}$ of $\mathrm{Na}_{2} \mathrm{CO}_{3}$ was added. Then, it was incubated at room temperature for $2 \mathrm{~h}$ in darkness, after which the absorption at $765 \mathrm{~nm}$ was measured (HP 8453, Hewlett Packard). The measurement was expressed as mg gallic acid (GA) kg ${ }^{-1} \mathrm{FW}$. Each one of the three replicates was analysed in triplicate (instrumental replicate).

The total antioxidant capacity of the leaves was evaluated in terms of their ability to deactivate the DPPH radical according to Brand-Williams et al. [25], with the modifications described by Lopez-Marín et al. [26]. Briefly, a solution of 2,2- diphenyl-1 picryhydrazil (DPPH) in methanol was prepared. A $25 \mu \mathrm{L}$ aliquot of the extract supernatant was mixed and $600 \mu \mathrm{L}$ of DPPH stock solution added. The homogenate was shaken vigorously and kept in darkness for 15-20 min at room temperature. The absorbance at $517 \mathrm{~nm}$ was measured in a spectrophotometer (HP 8453, Hewlett Packard). The measurement was expressed as mg DPPH reduced $\mathrm{kg}^{-1} \mathrm{FW}$.

The total flavonoids content was evaluated according to Meda et al. [27]. The procedure consisted of mixing $50 \mu \mathrm{L}$ of extract, $300 \mu \mathrm{L}$ of methanol and $350 \mu \mathrm{L}$ of a $2 \%$ $\mathrm{AlCl}_{3}$ dilution in methanol. After a $15 \mathrm{~min}$ incubation in darkness at room temperature, the absorbance at $430 \mathrm{~nm}$ was measured. The measurement was expressed as mg rutin $\mathrm{kg}^{-1} \mathrm{FW}$.

\subsection{Postharvest Product Handling and Analysis}

Leaves free from defects were sanitised in a cold room $\left(10^{\circ} \mathrm{C}\right)$ by immersion in a solution containing $100 \mathrm{ppm} \mathrm{NaClO}$ and $0.2 \mathrm{~g} \mathrm{~L}^{-1}$ citric acid $\left(2 \mathrm{~min}, 5{ }^{\circ} \mathrm{C}, \mathrm{pH}\right.$ 6.5). Then, they were rinsed with tap water $\left(2 \mathrm{~min}, 5{ }^{\circ} \mathrm{C}\right)$ and finally excess of water was removed by a salad spinner (30 s). Twenty g of leaves were placed in polypropylene (PP) baskets $(170 \mathrm{~mm} \times 120 \mathrm{~mm} \times 40 \mathrm{~mm})$ and thermo-sealed on the top with a $25 \mu \mathrm{m}$ thick film-oriented polypropylene (OPP). Three replicates for each irrigation treatment and storage time (processing day and after 6 and 12 days) were prepared and stored in darkness at $5{ }^{\circ} \mathrm{C}$. Each sampling day, and before opening the baskets, atmosphere composition within the package was measured. For that, a $0.5 \mathrm{~mL}$ sample of the headspace was withdrawn with a gas-tight syringe and $\mathrm{O}_{2}$ and $\mathrm{CO}_{2}$ concentrations were determined by a gas chromatograph (7820A GC Agilent Technologies, Waldbroon, Germany). The gas 
chromatograph conditions were: oven at $80^{\circ} \mathrm{C}$, injector and detector at $250{ }^{\circ} \mathrm{C}$, using $\mathrm{H}_{2}$ and air as gas carriers at $35 \mathrm{~mL} \mathrm{~min}{ }^{-1}$ and $350 \mathrm{~mL} \mathrm{~min}^{-1}$, respectively. A stainless-steel column packed with PorapakQ (1/8", 80/100 mesh size; Supelco Inc., Bellefonte, PA, USA) was used.

Microbial growth (mesophilic and psychrophilic aerobic bacteria, enterobacteria, and yeast and mould growth) was determined using standard enumeration methods. Samples of $1 \mathrm{~g}$ poured into a sterile stomacher bag (model 400 Bags 6141, London, UK) were homogenized with a $10 \mathrm{~mL}$ sterile peptone saline solution ( $\mathrm{pH} 7$; Scharlau Chemie SA, Barcelona, Spain) for $10 \mathrm{~s}$ in a masticator (Colwort Stomacher $400 \mathrm{Lab}$, Seward Medical, London, UK). For the enumeration of each microbial group, 10-fold dilution series were prepared in $9 \mathrm{~mL}$ of sterile peptone saline solution. Mesophilic, enterobacteria, and psychrotrophic were pour plated, and yeast and mould were spread plated. Media (Scharlau Chemie, Barcelona, Spain) and incubation conditions were as follows: plate count modified agar (PCA) for mesophilic and psychrotrophic aerobic bacteria $\left(30^{\circ} \mathrm{C}, 48 \mathrm{~h}\right.$ and $5^{\circ} \mathrm{C}$ for 7 days, respectively); violet red bile dextrose agar for enterobacteria $\left(37^{\circ} \mathrm{C}, 48 \mathrm{~h}\right)$; and rose Bengal agar for yeasts and moulds $\left(3-5\right.$ days, $\left.22^{\circ} \mathrm{C}\right)$. All microbial counts were reported as $\log$ colony forming units per gram of product $\left(\log \mathrm{CFU} \mathrm{g}{ }^{-1}\right)$. Each of the three replicates was analyzed by duplicate. The presence of Listeria monocytogenes was monitored according to the Regulation EC 1441/2007.

Weight loss was calculated as the difference between the initial weight of the samples at the beginning of storage and their final weight after 6 and 12 days. To normalize data, weight loss values were expressed as percentage of the initial value.

Firmness was measured at $22^{\circ} \mathrm{C}$ using a texturometer (Brookfield, Canada). A compression test was carried out with a blade ( $1 \mathrm{~mm}$ width) at a force of $90 \mathrm{~g}$ and a speed of $10.0 \mathrm{~mm} \mathrm{~s}^{-1}$ to reach a leave deformation of $0.5 \mathrm{~mm}$. Results were expressed in $\mathrm{g}$.

Leaf colour was determined on three points of each replicate using a colorimeter (Minolta CR-400 Series, Ramsey, NJ, USA). Tristimulus parameters ( $\left.\mathrm{L}^{*}, \mathrm{a}^{*}, \mathrm{~b}^{*}\right)$ of the CIE Lab system were used to calculate the Hue angle $=\arctan \left(b^{*} / a^{*}\right)$ and chroma $\left(C^{*}\right)=\left[\left(a^{*}\right) 2+\left(b^{*}\right)^{2}\right]^{1 / 2}$.

\subsection{Sensory Quality Panel}

Sensory quality was analysed according to international standards (ASTM 1986) in a standardised room (UNE-EN ISO 8589 2007) equipped with ten testing boxes. Samples coded with three random digit numbers were served at room temperature. Still mineral water was used as palate cleanser. Evaluation was performed by 10 trained judges on day 0 and after 6 and 12 days of storage at $5{ }^{\circ} \mathrm{C}$.

A 5-point scale was scored for colour, texture (crispness), flavour, aroma and global acceptance (5: excellent, 4: good, 3: fair, limit of usability, 2: poor; 1: extremely bad) and for defects as off-odours and mechanical damage (5: none; 4: slight; 3: moderate, limit of usability; 2: severe; 1: extreme) [28].

\subsection{Statistical Analysis}

A randomised complete block design with three replicates (beds) per both treatments, control and salinity, was used in the greenhouse. Each bed had three floating trays of $60 \mathrm{~cm} \times 41 \mathrm{~cm}$. Data were analysed using Statgraphics Plus. Analysis of variance (twoway ANOVA) was performed in which levels of salinity (9 and $150 \mathrm{mM}$ ), and storage time $(0,6$ and $12 d)$ were included. When interactions were significant, they were included in the ANOVA, a least significant difference test was performed to compare level of salinity, and storage time. When the variables were measured at harvesting time, only salinity factor was included. 


\section{Results}

\subsection{Growth, Yield, and Quality Characteristic of C. maritimum at Harvesting}

The salinity treatment did not affect the shoot FW and root parameters (Table 1). However, $\mathrm{NaCl}$ treatment reduced the leaf area and specific leaf area of $\mathrm{C}$. maritimum plants, which indicates that the leaves were thicker when plants were grown with $150 \mathrm{mM} \mathrm{NaCl}$.

Table 1. Influence of salinity treatment (control and $150 \mathrm{mM} \mathrm{NaCl}$ ) on fresh weight, leaf area, specific leaf area (SLA), total root length, area root, diameter root and volume root of $C$. maritimum at harvest.

\begin{tabular}{|c|c|c|c|c|c|c|c|}
\hline Treatments & $\begin{array}{c}\text { Shoot Fresh } \\
\text { Weight } \\
\text { (g plant }^{-1} \text { ) }\end{array}$ & $\begin{array}{l}\text { Shoot Dry } \\
\text { Weight } \\
\left(\text { g plant }^{-1}\right)\end{array}$ & $\begin{array}{l}\text { Leaf Area } \\
\left(\mathrm{cm}^{2}\right. \\
\left.\text { plant }^{-1}\right)\end{array}$ & $\begin{array}{c}\text { SLA } \\
\left(\mathrm{m}^{2} \mathrm{~kg}^{-1}\right)\end{array}$ & $\begin{array}{l}\text { Total Root } \\
\text { Length } \\
\text { (cm) }\end{array}$ & $\begin{array}{c}\text { Root } \\
\text { Diameter } \\
(\mathrm{mm})\end{array}$ & $\begin{array}{l}\text { Root Volume } \\
\qquad\left(\mathrm{cm}^{3}\right)\end{array}$ \\
\hline Control & $2.10 \pm 0.47 \mathrm{a}$ & $0.205 \pm 0.005 \mathrm{a}$ & $3.43 \pm 0.21 b$ & $0.19 \pm 0.012 b$ & $112.24 \pm 6.31 \mathrm{a}$ & $0.37 \pm 0.01 \mathrm{a}$ & $0.59 \pm 0.07 \mathrm{a}$ \\
\hline $\begin{array}{c}150 \mathrm{mM} \\
\mathrm{NaCl}\end{array}$ & $2.45 \pm 0.42 \mathrm{a}$ & $0.235 \pm 0.005 \mathrm{a}$ & $2.37 \pm 0.09 \mathrm{a}$ & $0.11 \pm 0.005 \mathrm{a}$ & $109.92 \pm 5.84 \mathrm{a}$ & $0.33 \pm 0.02 \mathrm{a}$ & $0.46 \pm 0.05 \mathrm{a}$ \\
\hline
\end{tabular}

Values are the mean $\pm \mathrm{SE}(n=6)$. Values in the same column with different letters for each anion differ significantly according to LSD test $(p<0.05)$.

Some differences were observed regarding the contents of anions and cations in the leaf of C. maritimum at harvesting (Tables 2 and 3). With regard to anions, the content of nitrate was reduced by $17 \%$ in salinity conditions, while the content of chloride was increased by 3.7-fold. Furthermore, the addition of $\mathrm{NaCl}$ significantly reduced the content of bromide and sulphate, while the content of phosphate and oxalate was not affected by the salinity. Regarding cations, the content of sodium was found to increase by ca. 500\%, whilst potassium, calcium and magnesium ions accumulated to a minor extent when sea fennel was grown in salinity conditions. These results agree with the hypothesis that sea fennel requires salt to grow, and it can tolerate high concentrations of salt. Finally, $\mathrm{Cl}^{-}$ content was found to be systematically higher than $\mathrm{Na}^{+}$, an imbalance that clearly indicates the existence in sea fennel plants of a regulatory mechanism to retain $\mathrm{Na}^{+}$far away from leaves since it could be a toxic element for the photosynthetic system.

Table 2. The content of anions $\left(\mathrm{NO}_{3}{ }^{-}, \mathrm{Cl}^{-}, \mathrm{Br}^{-}, \mathrm{PO}_{4}{ }^{3-}, \mathrm{SO}_{4}{ }^{2-}, \mathrm{C}_{2} \mathrm{O}_{4}{ }^{2-}\right)\left(\mathrm{mg} \mathrm{kg}^{-1} \mathrm{FW}\right)$ in the leaf of $C$. maritimum under the different treatments (control and $150 \mathrm{mM} \mathrm{NaCl}$ ) at harvesting.

\begin{tabular}{|c|c|c|c|c|c|c|}
\hline Treatments & $\mathrm{NO}_{3}{ }^{-}$ & $\mathrm{Cl}^{-}$ & $\mathrm{Br}^{-}$ & $\mathrm{PO}_{4}^{3-}$ & $\mathrm{SO}_{4}{ }^{2-}$ & $\mathrm{C}_{2} \mathrm{O}_{4}{ }^{2-}$ \\
\hline Control & $1530.31 \pm 586.47 \mathrm{~b}$ & $1810.97 \pm 120.56 \mathrm{a}$ & $152.00 \pm 2.82 \mathrm{~b}$ & $947.01 \pm 94.14 \mathrm{a}$ & $1699.55 \pm 32.28 b$ & $88.19 \pm 33.59 a$ \\
\hline $150 \mathrm{mM} \mathrm{NaCl}$ & $1263.03 \pm 19.79 \mathrm{a}$ & $6718.18 \pm 1029.31 b$ & $125.98 \pm 3.46 \mathrm{a}$ & $1154.39 \pm 142.73 \mathrm{a}$ & $671.25 \pm 47.66 \mathrm{a}$ & $88.70 \pm 28.87 a$ \\
\hline
\end{tabular}

Table 3. The content of cations $\left(\mathrm{Na}^{+}, \mathrm{K}^{+}, \mathrm{Ca}^{2+}, \mathrm{Mg}^{2+}\right)\left(\mathrm{mg} \mathrm{kg}^{-1} \mathrm{FW}\right)$ in the leaf of $C$. maritimum under the different treatments (control and $150 \mathrm{mM} \mathrm{NaCl}$ ) at harvesting.

\begin{tabular}{ccccc}
\hline Treatments & $\mathbf{N a}^{+}$ & $\mathbf{K}^{+}$ & $\mathbf{C a}^{2+}$ & $\mathbf{M g}^{2+}$ \\
\hline Control & $777.57 \pm 54.46 \mathrm{a}$ & $3642.49 \pm 109.48 \mathrm{~b}$ & $1108.29 \pm 20.91 \mathrm{~b}$ & $379.10 \pm 12.46 \mathrm{~b}$ \\
$150 \mathrm{mM} \mathrm{NaCl}$ & $4639.45 \pm 703.02 \mathrm{~b}$ & $1070.45 \pm 345.86 \mathrm{a}$ & $532.05 \pm 143.54 \mathrm{a}$ & $203.42 \pm 10.47 \mathrm{a}$ \\
\hline
\end{tabular}

Values are the mean \pm SE $(n=6)$. Values in the same column with different letters for each cation differ significantly according to LSD test $(p<0.05)$

Salinity significantly reduced the phenolics content in sea fennel leaves at harvesting by $6 \%$ but increased the flavonoids content by $10 \%$ (Table 4 ) However, no significant differences were found between treatments with respect to antioxidant capacity. 
Table 4. Total phenolics content, total flavonoids, and total antioxidant capacity in leaves of $C$. maritimum under the different treatments (control and $150 \mathrm{mM} \mathrm{NaCl}$ ).

\begin{tabular}{|c|c|c|c|}
\hline Treatments & $\begin{array}{l}\text { Total Phenolics } \\
\text { (mg GA kg }{ }^{-1} \text { FW) }\end{array}$ & $\begin{array}{c}\text { Total Flavonoids } \\
\left.\text { (mg Rutin } \mathrm{kg}^{-1} \mathrm{FW}\right)\end{array}$ & $\begin{array}{l}\text { Total Antioxidant Capacity } \\
\left(\mathrm{mg} \mathrm{DPPH}_{\text {reduced }} \mathrm{kg}^{-1} \mathrm{FW}\right)\end{array}$ \\
\hline Control & $887.43 \pm 11.95 b$ & $1966.89 \pm 45.17 \mathrm{a}$ & $112.24 \pm 6.31 \mathrm{a}$ \\
\hline $150 \mathrm{mM} \mathrm{NaCl}$ & $833.53 \pm 9.42 \mathrm{a}$ & $2167.24 \pm 22.09 \mathrm{~b}$ & $109.92 \pm 5.84 \mathrm{a}$ \\
\hline
\end{tabular}

Values are the mean \pm SE $(n=6)$. Values in the same column with different letters differ significantly according to LSD test $(p<0.05)$.

\subsection{Postharvest Quality}

Sea fennel leaves lost water moderately in both treatments during the storage time (data not shown). Particularly, after 12 days of storage, sea fennel leaves obtained from plants grown under salinity presented a higher weight loss $(1.24 \%)$ than those grown in the control $(0.32 \%)$.

Leaves' firmness (Table 5) was higher for control than for those grown under salty conditions and increased slightly during storage in both treatments, most likely related to lignification. The leaves of plants grown with $\mathrm{NaCl}$ treatment had less turgor due to higher dehydration, presenting lower firmness than the control.

Table 5. Effect of $150 \mathrm{mM} \mathrm{NaCl}$ addition in the nutrient solution on C. maritimum leaf firmness (mm) at 0,6 and 12 days of storage at $5{ }^{\circ} \mathrm{C}$.

\begin{tabular}{cc}
\hline & Sea Fennel Firmness (g) \\
\hline Salinity Treatment (A) & \\
Control & $596.27 \pm 20.43 \mathrm{~b}^{x}$ \\
$150 \mathrm{mM} \mathrm{NaCl}$ & $457.94 \pm 28.27 \mathrm{a}$ \\
Storage (B) & $494.48 \pm 35.26 \mathrm{a}{ }^{y}$ \\
0 days & $515.05 \pm 34.01 \mathrm{a}$ \\
6 days & $571.80 \pm 28.37 \mathrm{a}$ \\
12 days & $* * *$ \\
Significant Differences & $\mathrm{ns}$ \\
B & $\mathrm{ns}$ \\
A $\times$ B & \\
\hline
\end{tabular}

Asterisks indicates significance at ${ }^{* * *} p<0.001$; ns: non-significant. Different letters in the same column indicate significant differences. Values are the mean $\pm \mathrm{SE}\left({ }^{x} n=45,{ }^{y} n=30\right)$.

A passive modified atmosphere was generated inside the packages, which was related to the respiration rate of the produce. After 6 days of storage at $5{ }^{\circ} \mathrm{C}$, no differences in $\mathrm{O}_{2}$ and $\mathrm{CO}_{2}$ concentration in the atmosphere within the packages were observed between treatments (Figure 1). However, after 12 days of storage, $\mathrm{CO}_{2}$ concentration was slightly higher and $\mathrm{O}_{2}$ concentration was moderately lower within the baskets of sea fennel leaves grown with $150 \mathrm{mM} \mathrm{NaCl}$. It could indicate a higher respiration rate for these leaves, probably induced by the pre-harvest stressing conditions of salinity. However, the trend seems to be that both treatments were close to reaching the steady-state and, probably, at that moment differences between treatments would be minimal.

As regards the colour of the sea fennel leaves at harvest, the plants treated with $\mathrm{NaCl}$, presented a luminosity ( $\mathrm{L}^{*}$ parameter) about $6 \%$ higher than the control (Table 6 ). Due to that, hue values were lower for those leaves than for the control. Salinity slightly affected leaf colouration towards lighter colours. However, it was almost undetected by the sensory panel. The colour parameters did not change significantly over the 12 days of monitoring. Therefore, salinity did not adversely affect the colour, keeping marketability at values that resemble those of the control. 


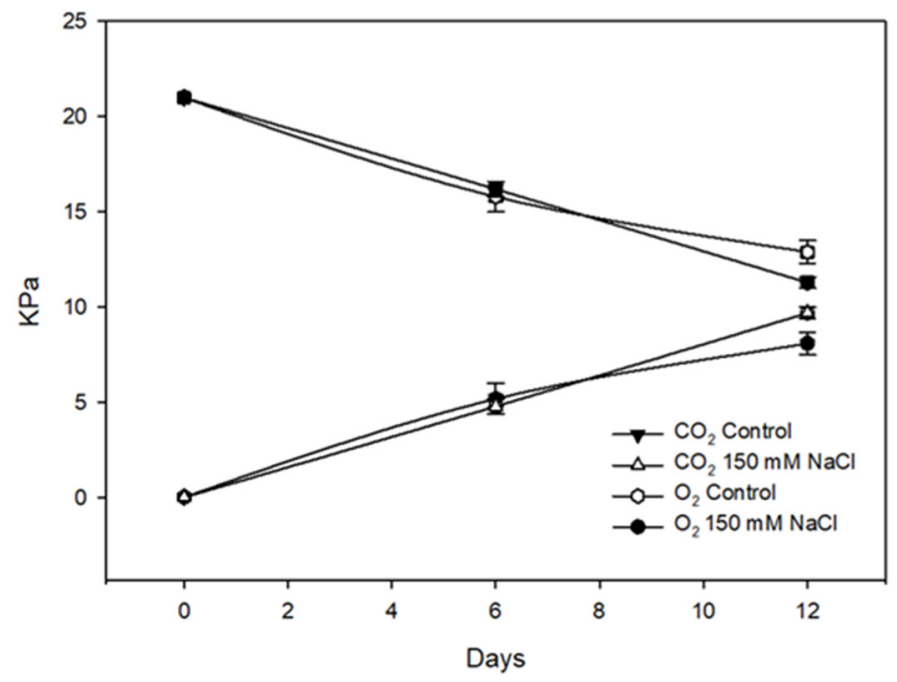

Figure 1. Effect of the salinity of the growing nutrient solution on the atmosphere composition within packages of fresh-cut sea fennel stored for $12 \mathrm{~d}$ at $5^{\circ} \mathrm{C}$. Values are the mean $\pm \operatorname{SE}(n=3)$.

Table 6. Effect of $150 \mathrm{mM} \mathrm{NaCl}$ addition in the nutrient solution on C. maritimum leaf colour parameters at 0,6 and 12 days of storage at $5^{\circ} \mathrm{C}$.

\begin{tabular}{|c|c|c|c|c|c|}
\hline & $\mathbf{L}$ & a & $\mathbf{b}$ & HUE & Chroma \\
\hline \multicolumn{6}{|c|}{ Salinity Treatment (A) } \\
\hline Control & $37.20 \pm 0.66 \mathrm{a}^{x}$ & $-11.31 \pm 0.39 \mathrm{a}$ & $18.32 \pm 1.01 \mathrm{a}$ & $121.98 \pm 1.08 \mathrm{~b}$ & $22.26 \pm 0.76 \mathrm{a}$ \\
\hline $150 \mathrm{mM} \mathrm{NaCl}$ & $39.14 \pm 0.40 \mathrm{~b}$ & $-10.94 \pm 0.27 \mathrm{a}$ & $20.62 \pm 0.55 a$ & $118.01 \pm 0.70 \mathrm{a}$ & $23.35 \pm 0.54 \mathrm{a}$ \\
\hline \multicolumn{6}{|l|}{ Storage (B) } \\
\hline 0 days & $38.51 \pm 0.62 \mathrm{a}^{y}$ & $11.29 \pm 0.42 \mathrm{a}$ & $20.25 \pm 1.12 \mathrm{a}$ & $119.43 \pm 1.96 \mathrm{a}$ & $21.09 \pm 0.94 \mathrm{a}$ \\
\hline 6 days & $37.95 \pm 1.07 \mathrm{a}$ & $10.84 \pm 0.36 a$ & $18.98 \pm 1.28 \mathrm{a}$ & $120.04 \pm 1.14 \mathrm{a}$ & $23.58 \pm 0.56 a$ \\
\hline 12 days & $38.04 \pm 0.66 \mathrm{a}$ & $11.26 \pm 0.49 \mathrm{a}$ & $19.18 \pm 0.94 \mathrm{a}$ & $120.51 \pm 1.04 \mathrm{a}$ & $22.71 \pm 0.98 \mathrm{a}$ \\
\hline \multicolumn{6}{|l|}{ Significant } \\
\hline \multicolumn{6}{|l|}{ Differences } \\
\hline $\mathrm{A}$ & $*$ & ns & ns & $*$ & ns \\
\hline B & ns & ns & ns & ns & ns \\
\hline $\mathrm{A} \times \mathrm{B}$ & ns & ns & ns & ns & ns \\
\hline
\end{tabular}

Microbial load (psychrophiles, yeast and moulds and enterobacteria) was higher at harvest for control leaves and increased during storage at $5{ }^{\circ} \mathrm{C}$. Listeria was not detected in any treatment. The results in Table 7 show that there was a significant interaction between salinity treatments and storage for psychrophilic bacteria, enterobacteria and yeast and mould counts.

Psychrophilic bacteria counts were significantly higher in control leaves at harvest, but after 6 days of storage, there were no significant differences between treatments (Figure 2). A similar trend was found for Enterobacteria.

The sensory quality, even when decreasing, was acceptable for both treatments at the end of storage (Table 8). The most important changes were observed in texture and freshness, mainly related to a lower crispness associated with the water loss. The leaves obtained from salinity had a salty taste which was not observed in the control. However, this hint of salt was not unpleasant. The samples did not present strange smells in any case. 
Table 7. Psychrophilic bacteria, mesophilic bacteria, enterobacteria and yeast and moulds counts (log CFU g ${ }^{-1}$ ) of $C$. maritimum leaves after different salinity treatment (control and $150 \mathrm{mM} \mathrm{NaCl}$ ) and storage at $5{ }^{\circ} \mathrm{C}$ for 0,6 and 12 days.

\begin{tabular}{|c|c|c|c|c|}
\hline & $\begin{array}{l}\text { Psychrophilic Bacteria } \\
\left(\log \text { UFC } g^{-1}\right)\end{array}$ & $\begin{array}{l}\text { Mesophilic Bacteria } \\
\quad\left(\log \mathrm{UFC}^{-1}\right)\end{array}$ & $\begin{array}{c}\text { Enterobacteria } \\
\left(\log \mathrm{UFC}^{-1}\right)\end{array}$ & $\begin{array}{l}\text { Yeast and Moulds } \\
\quad\left(\log \mathrm{UFC}^{-1}\right)\end{array}$ \\
\hline \multicolumn{5}{|c|}{ Salinity Treatment (A) } \\
\hline Control & $5.81 \pm 0.28 \mathrm{~b}^{x}$ & $5.40 \pm 0.31 \mathrm{a}$ & $5.15 \pm 0.38 b$ & $3.89 \pm 0.18 b$ \\
\hline $150 \mathrm{mM} \mathrm{NaCl}$ & $5.25 \pm 0.45 \mathrm{a}$ & $5.24 \pm 0.36 \mathrm{a}$ & $3.90 \pm 0.98 \mathrm{a}$ & $3.34 \pm 0.12 \mathrm{a}$ \\
\hline \multicolumn{5}{|l|}{ Storage (B) } \\
\hline 0 days & $4.23 \pm 0.44 \mathrm{a}^{y}$ & $4.05 \pm 0.11 \mathrm{a}$ & $1.89 \pm 0.83 \mathrm{a}$ & $3.09 \pm 0.16 \mathrm{a}$ \\
\hline 6 days & $5.99 \pm 0.08 b$ & $5.61 \pm 0.09 \mathrm{~b}$ & $5.61 \pm 0.13 b$ & $3.82 \pm 0.10 b$ \\
\hline 12 days & $6.38 \pm 0.01 b$ & $6.30 \pm 0.01 c$ & $6.21 \pm 0.07 c$ & $3.84 \pm 0.21 b$ \\
\hline \multicolumn{5}{|c|}{ Significant Differences } \\
\hline $\mathrm{A}$ & $*$ & ns & $* * *$ & $* *$ \\
\hline B & $* * *$ & $* * *$ & $* * *$ & $* *$ \\
\hline $\mathrm{A} \times \mathrm{B}$ & $*$ & ns & $* * *$ & ns \\
\hline
\end{tabular}

Asterisk indicates significances at ${ }^{*} p<0.05,{ }^{* *} p<0.01,{ }^{* * *} p<0.001$; ns: non-significant. Different letters in the same column indicate significant differences. Values are the mean $\pm \operatorname{SE}\left({ }^{x} n=9,{ }^{y} n=6\right)$.
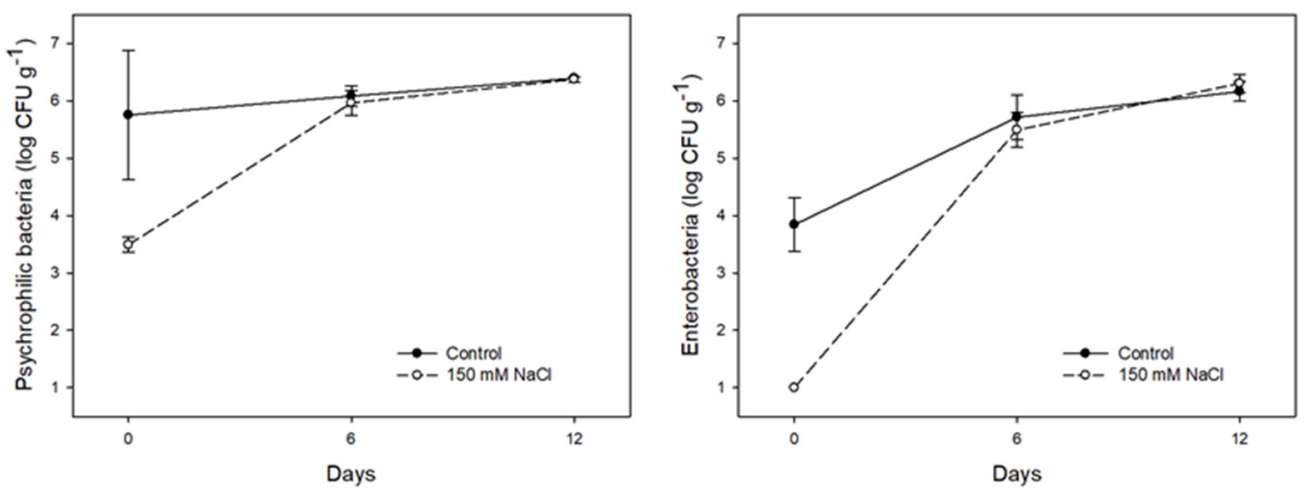

Figure 2. Psychrophilic bacteria and enterobacteria $\left(\log \mathrm{CFU} \mathrm{g} \mathrm{g}^{-1}\right)$ of $\mathrm{C}$. maritimum leaves with different salinity treatment (control and $150 \mathrm{mM} \mathrm{NaCl}$ ) after storage at $5{ }^{\circ} \mathrm{C}$ for 0,6 and 12 days. Values are the mean \pm SE $(n=3)$.

Table 8. Effect of $150 \mathrm{mM} \mathrm{NaCl}$ addition in the nutrient solution on sensory quality of $C$. maritimum leaves at 0,6 and 12 days of storage at $5^{\circ} \mathrm{C}$.

\begin{tabular}{|c|c|c|c|c|c|c|}
\hline \multicolumn{7}{|c|}{ Sensorial Quality } \\
\hline & \multicolumn{2}{|c|}{ Day 0} & \multicolumn{2}{|c|}{ Day 6} & \multicolumn{2}{|c|}{ Day 12} \\
\hline & Control & $150 \mathrm{mM} \mathrm{NaCl}$ & Control & $150 \mathrm{mM} \mathrm{NaCl}$ & Control & $150 \mathrm{mM} \mathrm{NaCl}$ \\
\hline \multicolumn{7}{|l|}{ Acceptance } \\
\hline Visual appearance & 5 & 4 & 4.5 & 4 & 4 & 3.5 \\
\hline Colour & 4 & 4 & 4 & 4 & 4 & 4 \\
\hline Texture (Crispness) & 5 & 5 & 4 & 3.5 & 3 & 3 \\
\hline Flavour (Freshness) & 5 & 4 & 4 & 4 & 3 & 3 \\
\hline Aroma & 5 & 5 & 5 & 5 & 5 & 5 \\
\hline Global acceptance & 5 & 4.5 & 4 & 3.5 & 3.5 & 3 \\
\hline \multicolumn{7}{|l|}{ Alterations } \\
\hline Off-odours & 5 & 5 & 5 & 5 & 5 & 5 \\
\hline Mechanical damage & 4 & 4 & 4 & 4 & 3.5 & 3.5 \\
\hline
\end{tabular}

\section{Discussion}

In this study the impact of salinity $(150 \mathrm{mM} \mathrm{NaCl})$ on plant growth, quality and self-life of C. maritimum was analysed. The salinity had no effect on the biomass and 
growth traits measured, indicating that sea fennel is a facultative halophyte with moderate tolerance to salinity, which does not require salt for maximal growth $[29,30]$. Similarly, Jiménez-Becker et al. [14] did not find differences in this species with respect to biomass growth when $\mathrm{NaCl}$ concentrations of $100 \mathrm{mM}, 200 \mathrm{mM}$, and $300 \mathrm{mM}$ were used. Nevertheless, the response to the salinity of $C$. maritimum is population-dependent, being this trait often correlated with the growth of the plants in their natural habitat [29]. The leaf area was reduced under $150 \mathrm{mM} \mathrm{NaCl}$, in agreement with previous results of Hamed et al. [29], provoking a reduction of the specific leaf area and consequently an increase in leaf thickness and succulence (measured as leaf FW:leaf area ratio [31], the latter being one of the major factors involved in plant salt tolerance, the main quality trait for stimulated growth in halophytes [32]. However, Jiménez-Becker et al. [14] detected a decrease in leaves FW:DW ratio (leaves succulence) together with a decrease in plant water content in the plants grown with $300 \mathrm{mM}$ with respect to that of those grown with $100 \mathrm{mM} \mathrm{NaCl}$; therefore, the salt concentration in the nutrient solution is one of the main factors to consider in leaf succulence of halophytes plants. It is important to bear in mind that succulence together with firmness and juiciness procure leaf texture, which is an important sensory attribute for determining the post-harvest quality and consumers' acceptance [33]. Consequently, acquiring leaf succulence in the crop cycle and keeping it during post-harvest through adequate technology could be a useful strategy for guaranteeing the quality and shelf-life of sea fennel.

Sea fennel can be also a good source of daily minerals required in a healthy diet. The increase in $\mathrm{Na}^{+}$and $\mathrm{Cl}^{-}$as the result of $\mathrm{NaCl}$ salinity was a common and expected response that was previously reported in sea fennel [32,34] since these elements are compartmentalized in vacuoles to avoid causing cytotoxicity [35]. However, differences between $\mathrm{Na}^{+}$ and $\mathrm{Cl}^{-}$accumulation in the aerial part were observed. It was postulated that differences in ion charge are responsible for the more expensive energetically sequestration of $\mathrm{Na}^{+}$ compared to the sequestration of $\mathrm{Cl}^{-}$, as the potential inside the vacuole is positive relative to the cytoplasm [36]. This would explain that the $\mathrm{Cl}^{-}$content in the aerial part was found to be systematically higher than $\mathrm{Na}^{+}$, under control and saline conditions. In this study, the $\mathrm{K}^{+} / \mathrm{Na}^{+}$ratio dropped dramatically with salinity treatment as it was reported in Tunisian [29,37] and Argelian C. maritimum populations [34], when increasing salinity concentrations were applied, although the degree of resilience was population dependent. Maintaining a high $\mathrm{K}^{+} / \mathrm{Na}^{+}$ratio is likely to be important to avoid the effects of ion toxicity under salt stress [38]. In our study, the accumulation of $\mathrm{Na}^{+}$in the control plant leaves was lower than in other halophytes [39]. In addition, $\mathrm{K}^{+}$was accumulated 4.68-fold higher than $\mathrm{Na}^{+}$, which could mean that sea fennel grown in a floating system could be suitable to cover part of the amount of $\mathrm{K}^{+}$required daily. However, due to the high $\mathrm{Na}^{+}$concentration, it would be better to use it as a meal accompaniment or as a condiment $[7,39]$, instead of as a main fresh vegetable dish. In control plants, $\mathrm{Ca}^{2+}$ concentration was 2 -fold than the $\mathrm{Ca}^{2+}$ accumulation found by Sánchez-Faure et al. [40] in sea fennel plants grown in their natural habitat. Despite saline treatment reducing the available $\mathrm{Ca}^{2+}$, its content in sea fennel leaves remained relatively high $\left(532.05 \mathrm{mg} \mathrm{kg}^{-1} \mathrm{FW}\right)$, with the potential benefit of preventing salt-induced oxidative damages, due to the protecting function of $\mathrm{Ca}^{2+}$ when plants face extreme heat, dry, or saline conditions [41,42]. The above-mentioned $\mathrm{Ca}^{2+}$ reduction with the salinity treatment could be due not only to the $\mathrm{Na}^{+}$accumulation but also to its reduce mobility and transport to the shoot under salinity stress [43,44]. An adequate $\mathrm{Ca}^{2+}$ intake for adults of $750 \mathrm{mg}$ per day was marked by EFSA. Therefore, $100 \mathrm{~g}$ of fresh sea fennel grown in our conditions may represent $15.8 \%$ (control plants) and $7.6 \%$ (plant grown with $150 \mathrm{mM} \mathrm{NaCl}$ ) of the daily recommended doses.

On the other hand, nitrate, bromide, and sulphate were reduced in the leaves of plants treated with $\mathrm{NaCl}$, confirming a reduction in the absorption capacity of nutrients by the roots under salt stress [45]. The difference in nitrate accumulation in response to salinity is generally linked with the inhibition of $\mathrm{NO}_{3}{ }^{-}$uptake by $\mathrm{Cl}^{-}$[46], which could happen by the interaction between these ions at the site of entry and for ion transport $[47,48]$. The 
nitrate content in the plants studied was generally quite low, and lower than the maximum legislated in the EU (Commission Regulation (EC) No 1258/2011) for other leafy vegetables such as spinach, lettuce, or rocket plant (2000-7000 $\mathrm{mg} \mathrm{kg}^{-1}$ ).

Salinity increased the content of total flavonoids but decreased phenolic content, while total antioxidant capacity was unaffected. Plants vary widely in their phenolic composition and content also accordingly to genetics and environmental conditions [49]. Our results agree with those of Labiad et al. [50], who demonstrated an increase in flavonoids content in $\mathrm{NaCl}$ treated sea fennel plants. Similarly, Yuan et al. [51] demonstrated on radish sprouts that moderate concentration of $\mathrm{NaCl}(100-150 \mathrm{mM})$ reduced total phenolic content while total antioxidant capacity remained unchanged. More recently, Emami Bistgani et al. [52] observed an increase in total phenolic content by around $20 \%$ after saline irrigation $(60 \mathrm{mM}$ $\mathrm{NaCl}$ ) was applied to Thymus vulgaris and Thymus daenensis, compared with control plants. Additionally, an increase in leaf flavonoid content by $38.6 \%$ and $36.6 \%$ was observed in plants grown under salt stress conditions after the application of 60 and $90 \mathrm{mM} \mathrm{NaCl}$. Plants cope with salinity-induced stress by altering metabolic processes and stimulating antioxidant activity to scavenge free radicals and ions chelators. Therefore, salt tolerance seems to be favoured by increased antioxidative compounds against oxidative stress induced by a toxic ion action [53]. Flavonoids are frequently induced by abiotic stress and promote roles in plant protection [54] as happened in our study. Hence, based on previous evidence and current data, it is possible to affirm that salt stress $(150 \mathrm{mM} \mathrm{NaCl})$ could be a feasible approach to keep, or even increase, the content of health-promoting compounds in C. maritimum.

Few studies have examined the storage conditions for edible halophytes leaves, with a clear lack of knowledge on C. maritimum shelf-life. The storage period of halophytes is usually limited to around a week, so high-tech storage and shipping conditions are required for longer periods [55]. The results presented here show that crop cultivation in controlled soilless conditions, even when salty, can yield production of high quality and good storability. The leaves kept their marketability until 12 days at $5{ }^{\circ} \mathrm{C}$. Concerning the colour, $\mathrm{NaCl}$ produced clearer leaves, probably due to the presence of salt crystals. To corroborate this, a detailed microscopy study would be needed. These results are in agreement with D'Imperio et al. [56] who found similar colour parameters on wild sea fennel collected along sea shoreline, which is the natural habitat of this species. Colour is among the first quality parameters catching the attention of consumers with a strong influence on consumers' choice and opinion about the food quality [1,7]. Changes of colour observed in our study were subtle and undetected by the trained sensory panel.

Modified atmosphere packaging is commonly used for fresh produce quality maintenance, prolonging shelf-life, and decreasing the microbial growth on perishable commodities [57]. The atmosphere reached in our experiments seems to be adequate, since no off-odours related to anaerobic metabolism were detected. The high relative humidity inside the packages made the weight loss almost negligible, indicating that the modified atmosphere is convenient for retaining succulence and firmness. The relatively lower firmness of leaves obtained from salinity did not affect the shelf-life.

The reduced microbial load at harvest for leaves grown with $150 \mathrm{mM} \mathrm{NaCl}$ would be related to the fact that they had less aerial biomass, so microorganisms appeared later and/or in fewer number than in the control samples. However, at the end of storage, that difference was negligible. Abadias et al. [58] obtained similar values $\left(10^{6}\right.$ to $\left.10^{7} \mathrm{CFU} \mathrm{g}^{-1}\right)$ of yeast and moulds in fresh-cut lettuce grown under salty conditions. Enterobacteriaceae, a common species in raw vegetables, even when reduced with $\mathrm{NaCl}$, was still present, being an indicator of contamination, that should be carefully avoided in a floating system. The absence of Enterobacteriaceae is an ideal starting point prior to storage and commercialisation. 


\section{Conclusions}

A saline-nutrient solution may be used successfully in hydroponic-grown sea fennel plants to enhance raw product quality and post-harvest shelf-life. The product presents a high concentration of flavonoids, a good sensory quality, and a reduction of microbial load. Consequently, it could be said that the saline treatment can be useful for the hydroponic culture of sea fennel obtaining a product with good marketability as an emerging crop for fresh consumption.

Nonetheless, variability in yields and chemical composition with geographical origins, harvesting and post-harvesting conditions needs to be explored and better understood prior to large-scale commercialisation for both farmers and consumers.

Author Contributions: Conceptualization, M.d.C.M.-B., C.E.-G. and J.A.F. (Juan A. Fernández); methodology, A.G., F.A. and J.A.F. (José A. Franco); formal analysis, A.S.; investigation, A.G., F.A. and P.A.G.; resources, A.S. and J.A.F. (Juan A. Fernández); data curation, A.G. and P.A.G.; writing—original draft preparation, F.A., A.G., P.A.G., M.d.C.M.-B. and J.A.F. (Juan A. Fernández); writing-review and editing C.E.-G., J.A.F. (José A. Franco), P.A.G., A.S., M.d.C.M.-B. and J.A.F. (Juan A. Fernández); supervision, J.A.F. (José A. Franco), C.E.-G., P.A.G. and M.d.C.M.-B.; funding acquisition, J.A.F. (Juan A. Fernández). All authors have read and agreed to the published version of the manuscript.

Funding: This research received no external funding.

Institutional Review Board Statement: Not applicable.

Informed Consent Statement: Not applicable.

Data Availability Statement: Not applicable.

Acknowledgments: The elaboration of the manuscript was supported by a grant from the University of Bari Aldo Moro (reference Premio di Studio GLOBAL THESIS) awarded to Fabio Amoruso.

Conflicts of Interest: The authors declare no conflict of interest.

\section{References}

1. Renna, M.; Gonnella, M.; Caretto, S.; Mita, G.; Serio, F. Sea fennel (Crithmum maritimum L.): From underutilized crop to new dried product for food use. Genet. Resour. Crop Evol. 2017, 64, 205-216. [CrossRef]

2. United States Department of Agriculture-Agriculture Research Service (USDA). U.S. National Plant Germplasm System [WWW Document]. Available online: https://npgsweb.ars-grin.gov/gringlobal/taxon/taxonomydetail?id=402237 (accessed on 15 November 2021).

3. Sánchez-Hernández, E.; Buzón-Durán, L.; Andrés-Juan, C.; Lorenzo-Vidal, B.; Martín-Gil, J.; Martín-Ramos, P. Physicochemical Characterization of Crithmum maritimum L. and Daucus carota subsp. gummifer (Syme) Hook. fil. and Their Antimicrobial Activity against Apple Tree and Grapevine Phytopathogens. Agronomy 2021, 11, 886. [CrossRef]

4. Atia, A.; Barhoumi, Z.; Mokded, R.; Abdelly, C.; Smaoui, A. Environmental eco-physiology and economical potential of the halophyte Crithmum maritimum L. (Apiaceae). J. Med. Plants Res. 2011, 5, 3564-3571.

5. Perez-Vizcaino, F.; Duarte, J.; Jiménez, R.; Santos-Buelga, C.; Osuna, A. Antihypertensive effects of the flavonoid quercetin. Pharmacol. Rep. 2009, 61, 67-75. [CrossRef]

6. Atzori, G.; de Vos, A.C.; van Rijsselberghe, M.; Vignolini, P.; Rozema, J.; Mancuso, S.; van Bodegom, P.M. Effects of increased seawater salinity irrigation on growth and quality of the edible halophyte Mesembryanthemum crystallinum L. under field conditions. Agric. Water Manag. 2017, 187, 37-46. [CrossRef]

7. Renna, M.; Gonnella, M. The use of the sea fennel as a new spice-colorant in culinary preparations. Int. J. Gastron. Food Sci. 2012, 1, 111-115. [CrossRef]

8. Siracusa, L.; Kulisic-Bilusic, T.; Politeo, O.; Krause, I.; Dejanovic, B.; Ruberto, G. Phenolic composition and antioxidant activity of aqueous infusions from Capparis spinosa L. and Crithmum maritimum L. before and after submission to a two-step in vitro digestion model. J. Agric. Food Chem. 2011, 59, 12453-12459. [CrossRef] [PubMed]

9. Giungato, P.; Renna, M.; Rana, R.; Licen, S.; Barbieri, P. Characterization of dried and freeze-dried sea fennel (Crithmum maritimum L.) samples with headspace gas-chromatography/mass spectrometry and evaluation of an electronic nose discrimination potential. Food Res. Int. 2019, 115, 65-72. [CrossRef]

10. Souid, A.; Della Croce, C.M.; Frassinetti, S.; Gabriele, M.; Pozzo, L.; Ciardi, M.; Abdelly, C.; Hamed, K.B.; Magné, C.; Longo, V. Nutraceutical potential of leaf hydro-ethanolic extract of the edible halophyte Crithmum maritimum L. Molecules 2021, 26, 5380. [CrossRef] 
11. Pistrick, K. Notes on neglected and underutilized crops Current taxonomical overview of cultivated plants in the families Umbelliferae and Labiatae. Genet. Resour. Crop Evol. 2002, 49, 211-221. [CrossRef]

12. Ozcan, B.; Tzeremes, P.G.; Tzeremes, N.G. Energy consumption, economic growth and environmental degradation in OECD countries. Econ. Model. 2020, 84, 203-213. [CrossRef]

13. Tran, D.Q.; Konishi, A.; Cushman, J.C.; Morokuma, M.; Toyota, M.; Agarie, S. Ion accumulation and expression of ion homeostasisrelated genes associated with halophilism, $\mathrm{NaCl}$-promoted growth in a halophyte Mesembryanthemum crystallinum L. Plant Prod. Sci. 2020, 23, 91-102. [CrossRef]

14. Jiménez-Becker, S.; Ramírez, M.; Plaza, B.M. The influence of salinity on the vegetative growth, osmolytes and chloride concentration of four halophytic species. J. Plant Nutr. 2019, 42, 1838-1849. [CrossRef]

15. Petropoulos, S.A.; Karkanis, A.; Martins, N.; Ferreira, I.C.F.R. Edible halophytes of the Mediterranean basin: Potential candidates for novel food products. Trends Food Sci. Technol. 2018, 74, 69-84. [CrossRef]

16. Renna, M.; Cocozza, C.; Gonnella, M.; Abdelrahman, H.; Santamaria, P. Elemental characterization of wild edible plants from countryside and urban areas. Food Chem. 2015, 177, 29-36. [CrossRef] [PubMed]

17. Renna, M. Reviewing the prospects of sea fennel (Crithmum maritimum L.) as emerging vegetable crop. Plants $2018,7,92$. [CrossRef]

18. Giménez, A.; Martínez-Ballesta, M.D.; Egea-Gilabert, C.; Gómez, P.A.; Artés-Hernández, F.; Pennisi, G.; Orsini, F.; Crepaldi, A.; Fernández, J.A. Combined Effect of Salinity and LED Lights on the Yield and Quality of Purslane (Portulaca oleracea L.) Microgreens. Horticulturae 2021, 7, 180. [CrossRef]

19. Nicola, S.; Fontana, E. Fresh-cut produce quality: Implications for a systems approach. In Postharvest Handling: A System Approach Florkowski, W.J., Shewfelt, R., Breuckner, B., Prussia, S.E., Eds.; Academic Press: San Diego, CA, USA; Elsevier: Amsterdam, The Netherlands, 2014; pp. 217-273.

20. Ali, A.Y.A.; Ibrahim, M.E.H.; Zhou, G.; Nimir, N.E.A.; Elsiddig, A.M.I.; Jiao, X.; Zhu, G.; Salih, E.G.I.; Suliman, M.S.E.S.; Elradi, S.B.M. Gibberellic acid and nitrogen efficiently protect early seedlings growth stage from salt stress damage in Sorghum. Sci. Rep. 2021, 11, 6672. [CrossRef]

21. Machado, R.; Serralheiro, R. Soil salinity: Effect on vegetable crop growth. Management practices to prevent and mitigate soil salinization. Horticulturae 2017, 3, 30. [CrossRef]

22. Egea-Gilabert, C.; Fernández, J.A.; Migliaro, D.; Martínez-Sánchez, J.J.; Vicente, M.J. Genetic variability in wild vs. cultivated Eruca vesicaria populations as assessed by morphological, agronomical and molecular analyses. Sci. Hortic. 2009, 121, 260-266. [CrossRef]

23. Lara, L.J.; Egea-Gilabert, C.; Niñirola, D.; Conesa, E.; Fernández, J.A. Effect of aeration of the nutrient solution on the growth and quality of purslane (Portulaca oleracea). J. Hortic. Sci. Biotechnol. 2011, 86, 603-610. [CrossRef]

24. Everette, J.D.; Bryant, Q.M.; Green, A.M.; Abbey, Y.A.; Wangila, G.W.; Walker, R.B. Thorough study of reactivity of various compound classes toward the folin-Ciocalteu reagent. J. Agric. Food Chem. 2010, 58, 8139-8144. [CrossRef] [PubMed]

25. Brand-Williams, W.; Cuvelier, M.-E.; Berset, C. Use of a free radical method to evaluate antioxidant activity. LWT-Food Sci. Technol. 1995, 28, 25-30. [CrossRef]

26. López-Marín, J.; Gálvez, A.; del Amor, F.M.; Albacete, A.; Fernández, J.A.; Egea-Gilabert, C.; Pérez-Alfocea, F. Selecting vegetative/generative/dwarfing rootstocks for improvingfruit yield and quality in water stressed sweet peppers. Sci. Hortic. 2017, 214, 9-17. [CrossRef]

27. Meda, A.; Lamien, C.E.; Romito, M.; Millogo, J.; Nacoulma, O.G. Determination of the total phenolic, flavonoid and proline contents in Burkina Fasan honey, as well as their radical scavenging activity. Food Chem. 2005, 91, 571-577. [CrossRef]

28. Tomás-Callejas, A.; López-Velasco, G.; Camacho, A.B.; Artés, F.; Artés-Hernández, F.; Suslow, T.V. Survival and distribution of Escherichia coli on diverse fresh-cut baby leafy greens under preharvest through postharvest conditions. Int. J. Food Microbiol. 2011, 151, 216-222. [CrossRef]

29. Hamed, K.B.; Debez, A.; Chibani, F.; Abdelly, C. Salt response of Crithmum maritimum, an oleagineous halophyte. Trop. Ecol. 2004, 45, 151-159.

30. Hamed, K.B.; Castagna, A.; Salem, E.; Ranieri, A.; Abdelly, C. Sea fennel (Crithmum maritimum L.) under salinity conditions: A comparison of leaf and root antioxidant responses. Plant Growth Regul. 2007, 53, 185-194. [CrossRef]

31. Amanullah; Khan, I.; Jan, A.; Jan, M.T.; Khalil, S.K.; Shah, Z.; Afzal, M. Compost and nitrogen management influence productivity of spring maize (Zea mays L.) under deep and conventional tillage systems in Semi-arid regions. Commun. Soil Sci. Plant Anal. 2015, 46, 1566-1578. [CrossRef]

32. Yepes, L.; Chelbi, N.; Vivo, J.-M.; Franco, M.; Agudelo, A.; Carvajal, M.; del Carmen Martinez-Ballesta, M. Analysis of physiological traits in the response of Chenopodiaceae, Amaranthaceae, and Brassicaceae plants to salinity stress. Plant Physiol. Biochem. 2018, 132, 145-155. [CrossRef]

33. Damerum, A.; Chapman, M.A.; Taylor, G. Innovative breeding technologies in lettuce for improved post-harvest quality. Postharvest Biol. Technol. 2020, 168, 111266. [CrossRef] [PubMed]

34. Hamdani, F.; Derridj, A.; Rogers, H.J. Diverse salinity responses in Crithmum maritimum tissues at different salinities over time. J. Soil Sci. Plant Nutr. 2017, 17, 716-734. [CrossRef] 
35. Ksouri, R.; Ksouri, W.M.; Jallali, I.; Debez, A.; Magné, C.; Hiroko, I.; Abdelly, C. Medicinal halophytes: Potent source of health promoting biomolecules with medical, nutraceutical and food applications. Crit. Rev. Biotechnol. 2012, 32, 289-326. [CrossRef] [PubMed]

36. Rea, P.A.; Poole, R.J. Vacuolar $\mathrm{H}^{+}$-translocating pyrophosphatase. Ann. Rev. Plant Physiol. Mol. Biol. 1993, 44, 157-180. [CrossRef]

37. Ben Hamed, K.; Ben Youssef, N.; Ranieri, A.; Zarrouk, M.; Abdelly, C. Changes in content and fatty acid profiles of total lipids and sulfolipids in the halophyte Crithmum maritimum under salt stress. J. Plant Physiol. 2005, 162, 599-602. [CrossRef] [PubMed]

38. Flowers, T.J.; Munns, R.; Colmer, T.D. Sodium chloride toxicity and the cellular basis of salt tolerance in halophytes. Ann. Bot. 2015, 115, 419-431. [CrossRef] [PubMed]

39. Castañeda-Loaiza, V.; Oliveira, M.; Santos, T.; Schüler, L.; Lima, A.R.; Gama, F.; Salazar, M.; Neng, N.R.; Nogueira, J.M.F.; Varela, J. Wild vs cultivated halophytes: Nutritional and functional differences. Food Chem. 2020, 333, 127536. [CrossRef] [PubMed]

40. Sánchez-Faure, A.; Calvo, M.M.; Pérez-Jiménez, J.; Martín-Diana, A.B.; Rico, D.; Montero, M.P.; del Carmen Gómez-Guillén, M.; López-Caballero, M.E.; Martínez-Alvarez, O. Exploring the potential of common iceplant, seaside arrowgrass and sea fennel as edible halophytic plants. Food Res. Int. 2020, 137, 109613. [CrossRef]

41. Jiang, Y.; Huang, B. Effects of calcium on antioxidant activities and water relations associated with heat tolerance in two cool-season grasses. J. Exp. Bot. 2001, 52, 341-349. [CrossRef]

42. Hernández, J.A.; Aguilar, A.B.; Portillo, B.; López-Gómez, E.; Beneyto, J.M.; García-Legaz, M.F. The effect of calcium on the antioxidant enzymes from salt-treated loquat and anger plants. Funct. Plant Biol. 2003, 30, 1127-1137. [CrossRef]

43. Coskun, D.; Britto, D.T.; Jean, Y.-K.; Kabir, I.; Tolay, I.; Torun, A.A.; Kronzucker, H.J. K+ efflux and retention in response to $\mathrm{NaCl}$ stress do not predict salt tolerance in contrasting genotypes of rice (Oryza sativa L.). PLoS ONE 2013, 8, e57767. [CrossRef] [PubMed]

44. Yuriko, O.; Osakabe, K.; Shinozaki, K.; Tran, L. SP Response of plants to water stress. Front. Plant Sci. 2014, 5, 86.

45. Chrysargyris, A.; Tzionis, A.; Xylia, P.; Tzortzakis, N. Effects of salinity on tagetes growth, physiology, and shelf life of edible flowers stored in passive modified atmosphere packaging or treated with ethanol. Front. Plant Sci. 2018, 9, 1765. [CrossRef] [PubMed]

46. Aslam, M.; Huffaker, R.C.; Rains, D.W. Early effects of salinity on nitrate assimilation in barley seedlings. Plant Physiol. 1984, 76, 321-325. [CrossRef]

47. Varma, S.; Rogers, D.M.; Pratt, L.R.; Rempe, S.B. Design principles for K+ selectivity in membrane transport. J. Gen. Physiol. 2011, 137, 479-488. [CrossRef]

48. Rubinigg, M.; Posthumus, F.; Ferschke, M.; Elzenga, J.T.M.; Stulen, I. Effects of NaCl salinity on $15 \mathrm{~N}$-nitrate fluxes and specific root length in the halophyte Plantago maritima L. Plant Soil 2003, 250, 201-213. [CrossRef]

49. De Abreu, I.N.; Mazzafera, P. Effect of water and temperature stress on the content of active constituents of Hypericum brasiliense Choisy. Plant Physiol. Biochem. 2005, 43, 241-248. [CrossRef]

50. Labiad, M.H.; Giménez, A.; Varol, H.; Tüzel, Y.; Egea-Gilabert, C.; Fernández, J.A.; Martínez-Ballesta, M.-C. Effect of exogenously applied methyl jasmonate on yield and quality of salt-stressed hydroponically grown sea fennel (Crithmum maritimum L.) Agronomy 2021, 11, 1083. [CrossRef]

51. Yuan, G.; Wang, X.; Guo, R.; Wang, Q. Effect of salt stress on phenolic compounds, glucosinolates, myrosinase and antioxidant activity in radish sprouts. Food Chem. 2010, 121, 1014-1019. [CrossRef]

52. Emami Bistgani, Z.; Hashemi, M.; DaCosta, M.; Craker, L.; Filippo, M.; Morshedloo, M.R. Effect of salinity stress on the physiological characteristics, phenolic compounds and antioxidant activity of Thymus vulgaris L. and Thymus daenensis Celak. Ind. Crops Prod. 2019, 135, 311-320. [CrossRef]

53. Rakhmankulova, Z.F.; Shuyskaya, E.V.; Shcherbakov, A.V.; Fedyaev, V.; Biktimerova, G.Y.; Khafisova, R.R.; Usmanov, I.Y. Content of proline and flavonoids in the shoots of halophytes inhabiting the South Urals. Russ. J. Plant Physiol. 2021, 62, 71-79. [CrossRef]

54. Grace, S.G.; Logan, B.A. Energy dissipation and radical scavenging by the plant phenylpropanoid pathway. Philos. Trans. R. Soc. Lond. Ser. B Biol. Sci. 2000, 355, 1499-1510. [CrossRef] [PubMed]

55. Gago, C.; Sousa, A.R.; Juliao, M.; Miguel, G.; Antunes, D.C.; Panagopoulos, T. Sustainable use of energy in the storage of halophytes used for food. Int. J. Energy Environ. 2011, 4, 592-599.

56. D'Imperio, M.; Renna, M.; Cardinali, A.; Buttaro, D.; Serio, F.; Santamaria, P. Calcium biofortification and bioaccessibility in soilless "baby leaf" vegetable production. Food Chem. 2016, 213, 149-156. [CrossRef] [PubMed]

57. Lopes, M.; Sanches-Silva, A.; Castilho, M.; Cavaleiro, C.; Ramos, F. Halophytes as source of bioactive phenolic compounds and their potential applications. Crit. Rev. Food Sci. Nutr. 2021, 2, 1-24. [CrossRef]

58. Abadias, M.; Usall, J.; Anguera, M.; Solsona, C.; Viñas, I. Microbiological quality of fresh, minimally-processed fruit and vegetables, and sprouts from retail establishments. Int. J. Food Microbiol. 2008, 123, 121-129. [CrossRef] [PubMed] 